\title{
Study on Preparation and Property of Ni-Co-P Coatings of AZ31B Magnesium Alloy
}

\author{
Xianguang Zeng ${ }^{1,2} \mathrm{a}^{*}$, Xingwen Zheng ${ }^{1, \mathrm{~b}}$, Hong Luo ${ }^{1, \mathrm{c}}$, Xiuzhou Lin ${ }^{1,2, \mathrm{~d}}$, and \\ Xiaolang Jiang ${ }^{1, \mathrm{e}}$
}

${ }^{1}$ Institute of Material and Chemical Engineering, Sichuan University of Science and Engineering,

\author{
Zigong, Sichuan, 643000, China \\ ${ }^{2}$.Material Corrosion and Protection Key Laboratory of Sichuan Province, Zigong 643000, China \\ a* hnzxg1979@126.com, 'bxwasd@126.com, 9luohong28@163.com, ${ }^{\mathrm{d}}$ linxiuzhou@163.com, \\ e1252585567@qq.com
}

\begin{abstract}
Keywords:Magnesium alloy,Electroless,Ni-Co-P,Orthogonal experiment method,Corrosion resistance

Abstract. AZ31B was used as the basic material in electroless Plating of Ni-Co-P, The optimium formula and process conditions were obtained by using the orthogonal experiment methods. XRD, SEM and EDS were used to characterize phase structure,compositon and morphology of Ni-Co-P coating. The morphology,corrosion resistance, composition, hardness, thickness and binding force of coating are measured and analysed. The optimum formula and the technological conditions were gained as follows: $26.0 \mathrm{~g} / \mathrm{L} \mathrm{NiSO}_{4} \cdot 6 \mathrm{H}_{2} \mathrm{O}, 28.0 \mathrm{~g} / \mathrm{L} \mathrm{CoSO} \cdot 7 \mathrm{H}_{2} \mathrm{O}, 24.0 \mathrm{~g} / \mathrm{L} \mathrm{NaH} \mathrm{PO}_{2} \cdot \mathrm{H}_{2} \mathrm{O}, 80.0 \mathrm{~g} / \mathrm{L}$ $\mathrm{Na}_{3} \mathrm{C}_{6} \mathrm{H}_{5} \mathrm{O}_{7} \cdot 2 \mathrm{H}_{2} \mathrm{O}, 60.0 \mathrm{~g} / \mathrm{L} \mathrm{NH} \mathrm{NH}_{4} \mathrm{~F}$, temperature of $90.0^{\circ} \mathrm{C}, 0.001 \mathrm{~g} / \mathrm{L} \mathrm{KI}, 0.05 \mathrm{~g} / \mathrm{L}$ SDBS ,the plating time of $2.0 \mathrm{~h}$ and $\mathrm{pH}$ of 8.0.Under this condition, the coating had stronger corrosion resistance, drop time for $\mathrm{KMnO}_{4}$ solution was $272 \mathrm{~s}$; The hardnesses was $229.60 \mathrm{HV}$; the deposition rate was faster, up to $53.33 \mathrm{~g} \cdot \mathrm{m}^{-2} \cdot \mathrm{h}^{-1}$; thickness was $12.43 \mu \mathrm{m}$; the surface of the coating was uniform; the distribution of porosity was smaller; there was well-bonded with the substrate.
\end{abstract}

\section{Introduction}

The electroless plating of Ni-P was controlled by auto-catalytic reduction of metallic salt complexes occurring on the substrate. Electroless deposition offered an alternate and attractive methods of producing a thin and uniform coating, and it had been known to obtain a Special performance coating when compared to electroplating.Electroless Ni-Co-P alloy had advantages from both Ni-P alloy and Co-P alloy . Ni-Co-P alloy coating possed unique properties such as high coercive force, the smaller residual magnetism, high wear resistance, high corrosion resistance and high density magnetic that were widely used in compact disk, MEMS, surface anti-corrosion, aerospace and other fields ${ }^{[1-6]}$. In the present,main preparation methods consisted of electroless plating method, electroplating method and sputtering method, etc., in which the electroless plating was a common method for obtaining Ni-Co-P alloy.Although the plating rate, stability and bath life subjected to certain restrictions, but because of its simple operation, uniform coating, high density and hardness characteristics, it had been widely used in many fields ${ }^{[7-11]}$.In this paper, the AZ31B magnesium alloy was used as matrix to make electroless Ni-Co-P alloy under the alkaline conditions. the formula and process conditions of Ni-Co-P were systematically studied. Furthermore, it could improve the existing problems such as slow plating speed and coating corrosion resistance, and lay a good foundation for the development and application in the future. 


\section{Experimental}

\section{Materials and Experiment Reagent}

Die-casted AZ31B magnesium alloy that were purchased from Dongguan Yuelute Industries Co., Ltd (China) was the experimental materials used for the investigation. Samples with sizes $50 \times 25 \times 2 \mathrm{~mm}$ were cut and the substrate was metallographically ground with sand paper with different grits (180, $320,600,800,1200)$ step by step before the pretreatment processed. The chemical compositions were shown in Tab.1. $\mathrm{NiSO}_{4} \cdot 6 \mathrm{H}_{2} \mathrm{O}, \mathrm{NaH}_{2} \mathrm{PO}_{2} \cdot \mathrm{H}_{2} \mathrm{O}$, SDBS, KI , $\mathrm{Na}_{3} \mathrm{C}_{6} \mathrm{H}_{5} \mathrm{O}_{7} \cdot 2 \mathrm{H}_{2} \mathrm{O}$ were supplied by Chengdu Kelong Chemical Reagent Factory. $\mathrm{C}_{2} \mathrm{H}_{5} \mathrm{OH}, \mathrm{H}_{3} \mathrm{PO}_{4},\left(\mathrm{NH}_{4}\right) \mathrm{HF}_{2}, \mathrm{Na}_{2} \mathrm{CO}_{3}$ and $\mathrm{NaF}$ were purchased from Chongqing Chuandong Chemical (Group) Co., Ltd. Other chemicals were purchased from Chongqing Beibei Chemical Reagent Factory. All chemicals were of analytical grade and used as received without further purification. Distilled water was used throughout the work.

Tab.1 Chemical compositions of AZ31B magnesium alloy

\begin{tabular}{ccccccccc}
\hline Element & $\mathrm{Mg}$ & $\mathrm{Si}$ & $\mathrm{Fe}$ & $\mathrm{Al}$ & $\mathrm{Ca}$ & $\mathrm{Mn}$ & $\mathrm{Zn}$ & $\mathrm{Be}$ \\
\hline Wt.\% & 95.52 & 0.03 & 0.05 & 3.10 & 0.05 & 0.33 & 0.82 & 0.10 \\
\hline
\end{tabular}

\section{Electroless Plating Process}

Electroless plating process involved a combination in turn:magnesium alloy samples washing $\rightarrow$ sanding $\rightarrow$ acetone degreasing $\rightarrow$ derusting $\rightarrow$ washing $\rightarrow$ pickling $\rightarrow$ activation $\rightarrow$ washing $\rightarrow$ Zincating $\rightarrow$ electroless plating $\rightarrow$ washing $\rightarrow$ drying $\rightarrow$ weighing $\rightarrow$ performance testing. What deserved to be mentioned the most was the zincating process which was repeated twice, each one for 20 s.It contributed to improve the plating rate and performance of coating. Zincating process was shown as follows : It was conducted in a $\mathrm{ZnSO}_{4} \cdot 6 \mathrm{H}_{2} \mathrm{O}, \mathrm{K}_{4} \mathrm{P}_{2} \mathrm{O}_{7}, \mathrm{NaF}$, and $\mathrm{Na}_{2} \mathrm{CO}_{3}$ mixed solution at $80^{\circ} \mathrm{C}$ for $1 \mathrm{~h}$. Its compositions were fixed as $\left(30 \mathrm{~g} \mathrm{ZnSO}_{4} \cdot 6 \mathrm{H}_{2} \mathrm{O}, 100 \mathrm{~g} \mathrm{~K}_{4} \mathrm{P}_{2} \mathrm{O}_{7}, 5 \mathrm{~g} \mathrm{NaF}\right.$ and $5 \mathrm{~g}$ $\mathrm{Na}_{2} \mathrm{CO}_{3}$ ) in $1 \mathrm{~L} \mathrm{H}_{2} \mathrm{O}$. Between the two zincating processes, $\mathrm{AZ31B}$ was cleaned in distilled water and $1 \mathrm{M} \mathrm{H}_{2} \mathrm{SO}_{4}$ solution with each one for $15 \mathrm{~s}$.

\section{Characterization}

The surface appearance of as-prepared Ni-Co-P alloy coating was detected by GB/T 11376-1997. Its morphology and composition was examined by SEM (Model VEGA 3, Czech) and EDS (Bruker EDS QUANTAX) respectively. Potentiodynamic polarization technique was applied to study the general corrosion resistance parameters of bare AZ31B and as-deposited $\mathrm{Ni}-\mathrm{Co}-\mathrm{P}$ alloy coating. It was performed using CHI660D electrochemical workstation (Shanghai Chenhua Instruments, China) in a conventional three-electrode system, AZ31B and Ni-Co-P alloy coating electrode were used as the working electrode.A platinum electrode and a saturated calomel electrode(SCE)were used as the counter and reference electrodes, respectively. The working electrode was immersed in $3.5 \% \mathrm{NaCl}$ solution at $90{ }^{\circ} \mathrm{C}$ and left until the steady-state open circuit potential was attained. It was taken as the free corrosion potential. Thereafter, potentiodynamic polarization measurements were recorded at a scan rate of $2 \mathrm{mVs}-1$, starting from $-1000 \mathrm{mV}$ to $0 \mathrm{mV}$ versus reference electrode. Binding force of coating was tested according to GB/T 13913-2008. According to HB5061-77 (magnesium alloy chemical oxidation film layer quality inspection), $\mathrm{KMnO}_{4}$ drop solution methods was conducted to record the color changing time. Formula of $\mathrm{KMnO}_{4}$ drop solution was shown in Tab.2. In general, drop time for $\mathrm{KMnO}_{4}$ solution became longer, the corrosion resistance of coating appeared to get stronger. Coating porosity was attained according to GB/T 5935-1986 with filter paper method. The thickness of coating was measured by metallographic methods ${ }^{[12]}$. Crystal structure and crystallinity of as-prepared Ni-Co-P alloy coating was investigated by XRD (DX-2600,China) in a $2 \theta$ range from 15 to $75^{\circ}$ with a wavelength $\lambda=0.15406 \mathrm{~nm}$ and $35 \mathrm{kV} / 30 \mathrm{~mA}$. 
Tab.2 Formula of $\mathrm{KMnO}_{4}$ drop solution

\begin{tabular}{cccc}
\hline Experiment Reagent & $\mathrm{KMnO}_{4}(\mathrm{~g})$ & $\mathrm{HNO}_{3}(\mathrm{~mL})$ & $\mathrm{H}_{2} \mathrm{O}(\mathrm{mL})$ \\
\hline Dosage & 0.05 & 5 & 95 \\
\hline
\end{tabular}

orthogonal experiment method

With reference to domestic and foreign research and a large number of preliminary experiments related to ternary electroless, available concentration range of in basic plating solution and process parameters were determined as follows: $\mathrm{CoSO}_{4} \cdot 7 \mathrm{H}_{2} \mathrm{O} 24.0-28.0 \mathrm{~g} / \mathrm{L}, \mathrm{NiSO}_{4} \cdot 6 \mathrm{H}_{2} \mathrm{O} \quad 26.0-30.0$ $\mathrm{g} / \mathrm{L}, \mathrm{NaH}_{2} \mathrm{PO}_{2} \cdot \mathrm{H}_{2} \mathrm{O} 18.0-24.0 \mathrm{~g} / \mathrm{L}, \mathrm{Na}_{3} \mathrm{C}_{6} \mathrm{H}_{5} \mathrm{O}_{7} \cdot 2 \mathrm{H}_{2} \mathrm{O} 75.0-85.0 \mathrm{~g} / \mathrm{L}, \mathrm{NH}_{4} \mathrm{~F} \quad 60.0-80.0 \mathrm{~g} / \mathrm{L}$, plating time $1.5-2.5 \mathrm{~h}$ and temperature $80-90^{\circ} \mathrm{C}$. At the same time, stabilizer $\mathrm{KI} 0.001 \mathrm{~g} / \mathrm{L}$, the surfactant SDBS $0.05 \mathrm{~g} / \mathrm{L}$ and $\mathrm{PH}$ value of 8.0 were fixed in plating solution throughout the experiment.On the base of preliminary experiment , an orthogonal test table $\mathrm{L}_{18}\left(3^{7}\right)$ was used with seven factors, namely $\mathrm{CoSO}_{4} \cdot 7 \mathrm{H}_{2} \mathrm{O}$ concentration, $\mathrm{NiSO}_{4} \cdot 6 \mathrm{H}_{2}$ Oconcentration, $\mathrm{NaH}_{2} \mathrm{PO}_{2} \cdot \mathrm{H}_{2} \mathrm{O}$ concentration, $\mathrm{Na}_{3} \mathrm{C}_{6} \mathrm{H}_{5} \mathrm{O}_{7} \cdot 2 \mathrm{H}_{2} \mathrm{O}$ concentration, $\mathrm{NH}_{4} \mathrm{~F}$ concentration, time and temperature. In addition, $\mathrm{KMnO}_{4}$ drop time for $\mathrm{KMnO}_{4}$ solution were taken as an indicator, This study used $\mathrm{L}_{18}\left(3^{7}\right)$ orthogonal table to take orthogonal test was performed to attain optimum formula and process condition.orthogonal test design was shown in Tab. $1^{[13]}$.

Tab.3 Factor and level of orthogonal experiment

\begin{tabular}{llllllll}
\hline & \multicolumn{7}{c}{ Factor } \\
\cline { 2 - 8 } Level & $\mathrm{A}(\mathrm{g} / \mathrm{L})$ & $\mathrm{B}(\mathrm{g} / \mathrm{L})$ & $\mathrm{C}(\mathrm{g} / \mathrm{L})$ & $\mathrm{D}(\mathrm{g} / \mathrm{L})$ & $\mathrm{E}(\mathrm{g} / \mathrm{L})$ & $\mathrm{F}\left({ }^{\circ} \mathrm{C}\right)$ & $\mathrm{G}(\mathrm{h})$ \\
& $\mathrm{CoSO} \cdot 7 \mathrm{H}_{2}$ & $\mathrm{NiSO}_{4} \cdot 6 \mathrm{H}_{2}$ & $\mathrm{NaH}_{2} \mathrm{PO}_{2} \cdot \mathrm{H}_{2}$ & $\mathrm{Na}_{3} \mathrm{C}_{6} \mathrm{H}_{5} \mathrm{O}_{7} \cdot 2 \mathrm{H}_{2}$ & $\mathrm{NH}_{4} \mathrm{~F}$ & $\mathrm{~T}$ & Plating \\
& $\mathrm{O}$ & $\mathrm{O}$ & $\mathrm{O}$ & $\mathrm{O}$ & & & Time \\
\hline 1 & 24.0 & 26.0 & 18.0 & 75.0 & 60.0 & 80.0 & 1.5 \\
2 & 26.0 & 28.0 & 22.0 & 80.0 & 70.0 & 85.0 & 2.0 \\
3 & 28.0 & 30.0 & 24.0 & 85.0 & 80.0 & 90.0 & 2.5 \\
\hline
\end{tabular}

\section{Results and Discussion}

\section{Optimium technological parameters of electroless}

Arranged the tests based on $\mathrm{L}_{18}\left(3^{7}\right)$ orthogonal test design table, Orthogonal experiment results were shown in Tab. 4. 
Tab. 4 Orthogonal experiment results

\begin{tabular}{|c|c|c|c|c|c|c|c|c|}
\hline \multirow[b]{2}{*}{ Level } & \multicolumn{7}{|c|}{ Factor } & \multirow[b]{2}{*}{$\begin{array}{l}\text { Drop } \\
\text { time } \\
(\mathrm{s}) \\
\end{array}$} \\
\hline & $\begin{array}{l}\mathrm{CoSO}_{4} \cdot \\
7 \mathrm{H}_{2} \mathrm{O} \\
(\mathrm{g} / \mathrm{L}) \\
\end{array}$ & $\begin{array}{l}\mathrm{NiSO}_{4} \cdot 6 \\
\mathrm{H}_{2} \mathrm{O} \\
(\mathrm{g} / \mathrm{L}) \\
\end{array}$ & $\begin{array}{c}\mathrm{NaH}_{2} \mathrm{PO}_{2} \cdot \\
\mathrm{H}_{2} \mathrm{O} \\
(\mathrm{g} / \mathrm{L}) \\
\end{array}$ & $\begin{array}{c}\mathrm{Na}_{3} \mathrm{C}_{6} \mathrm{H}_{5} \mathrm{O} \\
{ }_{7} \cdot 2 \mathrm{H}_{2} \mathrm{O} \\
(\mathrm{g} / \mathrm{L}) \\
\end{array}$ & $\begin{array}{l}\mathrm{NH}_{4} \mathrm{~F} \\
(\mathrm{~g} / \mathrm{L})\end{array}$ & $\begin{array}{c}\mathrm{T} \\
\left({ }^{\circ} \mathrm{C}\right)\end{array}$ & $\begin{array}{l}\text { Plating } \\
\text { time } \\
\text { (h) }\end{array}$ & \\
\hline 1 & 24.0 & 26.0 & 18.0 & 75.0 & 60.0 & 80.0 & 1.5 & 94 \\
\hline 2 & 24.0 & 28.0 & 22.0 & 80.0 & 70.0 & 85.0 & 2.0 & 92 \\
\hline 3 & 24.0 & 30.0 & 24.0 & 85.0 & 80.0 & 90.0 & 2.5 & 210 \\
\hline 4 & 24.0 & 26.0 & 22.0 & 85.0 & 60.0 & 85.0 & 2.5 & 133 \\
\hline 5 & 24.0 & 28.0 & 3 & 75.0 & 70.0 & 90.0 & 1.5 & 172 \\
\hline 6 & 24.0 & 30.0 & 18.0 & 80.0 & 80.0 & 80.0 & 2.0 & 141 \\
\hline 7 & 26.0 & 26.0 & 24.0 & 80.0 & 60.0 & 90.0 & 2.0 & 188 \\
\hline 8 & 26.0 & 28.0 & 18.0 & 85.0 & 70.0 & 80.0 & 2.5 & 152 \\
\hline 9 & 26.0 & 30.0 & 22.0 & 75.0 & 80.0 & 85.0 & 1.5 & 121 \\
\hline 10 & 26.0 & 26.0 & 18.0 & 75.0 & 60.0 & 80.0 & 1.5 & 221 \\
\hline 11 & 26.0 & 28.0 & 22.0 & 80.0 & 70.0 & 85.0 & 2.0 & 198 \\
\hline 12 & 26.0 & 30.0 & 24.0 & 85.0 & 80.0 & 90.0 & 2.5 & 251 \\
\hline 13 & 28.0 & 26.0 & 22.0 & 85.0 & 60.0 & 85.0 & 2.5 & 132 \\
\hline 14 & 28.0 & 28.0 & 24.0 & 75.0 & 70.0 & 90.0 & 1.5 & 201 \\
\hline 15 & 28.0 & 30.0 & 18.0 & 80.0 & 80.0 & 80.0 & 2.0 & 197 \\
\hline 16 & 28.0 & 26.0 & 24.0 & 80.0 & 60.0 & 90.0 & 2.0 & 272 \\
\hline 17 & 28.0 & 28.0 & 18.0 & 85.0 & 70.0 & 80.0 & 2.5 & 215 \\
\hline 18 & 28.0 & 30.0 & 22.0 & 75.0 & 80.0 & 85.0 & 1.5 & 178 \\
\hline $\mathrm{K} 1$ & 842.0 & 1098 & 1020.0 & 1088.0 & 1098 & 1020.0 & 987.0 & \\
\hline $\mathrm{K} 2$ & 1131.0 & 1030 & 854.0 & 1093.0 & 1077.0 & 854.0 & 1093.0 & \\
\hline $\mathrm{K} 3$ & 1195.0 & 1040 & 1294.0 & 987.0 & 1040.0 & 1294.0 & 1088.0 & \\
\hline $\mathrm{R}$ & 353.0 & 68.0 & 274.0 & 106.0 & 58.0 & 440.0 & 106.0 & \\
\hline
\end{tabular}

Plating solution generally consisted of main salt, reducing agent, complexing agent, buffer, stabilizing agent, accelerating agent and Surfactant. Functions of various additives in the plating solution were not the same.To be specific, $\mathrm{CoSO}_{4} \cdot 7 \mathrm{H}_{2} \mathrm{O}$ and $\mathrm{NiSO}_{4} \cdot 6 \mathrm{H}_{2} \mathrm{O}$ were main salt, $\mathrm{NaH}_{2} \mathrm{PO}_{2} \cdot \mathrm{H}_{2} \mathrm{O}, \mathrm{Na}_{3} \mathrm{C}_{6} \mathrm{H}_{5} \mathrm{O}_{7} \cdot 2 \mathrm{H}_{2} \mathrm{O}$, KI and SDBS were reducing agent , complexing agent ,stabilizing agent and surfactant respectively, $\mathrm{NH}_{4} \mathrm{~F}$ were both buffer and accelerating agent. It was worth mentioning that the buffer property rised When a certain amount of $\mathrm{NH}_{4} \mathrm{~F}$ was added in plating solution. Meanwhile ,Mechanism of $\mathrm{NH}_{4} \mathrm{~F}$ in the the electroless mainly was that $\mathrm{F}^{-}$accelerated $\mathrm{H}-\mathrm{P}$ bond rupture for $\mathrm{H}_{2} \mathrm{PO}_{2}{ }^{-}$to reduce the activation energy of electroless nickel plating reaction on substrate surface and chemical reaction producted with the solvent. Moreover, $\mathrm{NH}_{4}{ }^{+}$also played the role of chelating metal ion.In general, the greater range $\mathrm{R}$ indicated that the factor was more important. Tab. 3 showed the size of range are that: $\mathrm{RF}>\mathrm{RA}>\mathrm{RC}>\mathrm{RD}=\mathrm{RG}>\mathrm{RB}>\mathrm{RE}$, so the orders of several 
factors affecting the performance of coating were as follows: temperature $>\mathrm{CoSO}_{4} \cdot 7 \mathrm{H}_{2} \mathrm{O}>$ $\mathrm{NaH}_{2} \mathrm{PO}_{2} \cdot \mathrm{H}_{2} \mathrm{O}>\mathrm{Na}_{3} \mathrm{C}_{6} \mathrm{H}_{5} \mathrm{O}_{7} \cdot 2 \mathrm{H}_{2} \mathrm{O}=$ Plating time $>\mathrm{NiSO}_{4} \cdot 6 \mathrm{H}_{2} \mathrm{O}>\mathrm{NH}_{4} \mathrm{~F}$. Therefore, the best methods could be concluded that: A3B1C3D2E1F3G2, namely the optimun formula and process condition as follows: $26.0 \mathrm{~g} / \mathrm{L} \mathrm{NiSO} \cdot 6 \mathrm{H}_{2} \mathrm{O} \quad, \quad 28.0 \mathrm{~g} / \mathrm{L} \mathrm{CoSO} \mathrm{CoS}_{4} \cdot 7 \mathrm{H}_{2} \mathrm{O}, \quad 24.0 \mathrm{~g} / \mathrm{L} \quad \mathrm{NaH}_{2} \mathrm{PO}_{2} \cdot \mathrm{H}_{2} \mathrm{O}, \quad 80.0 \mathrm{~g} / \mathrm{L}$ $\mathrm{Na}_{3} \mathrm{C}_{6} \mathrm{H}_{5} \mathrm{O}_{7} \cdot 2 \mathrm{H}_{2} \mathrm{O}, 60.0 \mathrm{~g} / \mathrm{L} \mathrm{NH} \mathrm{F}_{4} \mathrm{~F}$, temperature of $90.0^{\circ} \mathrm{C}, 0.001 \mathrm{~g} / \mathrm{L} \mathrm{KI}, 0.05 \mathrm{~g} / \mathrm{L} \mathrm{SDBS}$, the plating time of $2.0 \mathrm{~h}$ and $\mathrm{pH}$ of 8.0 .According to the optimun formula and process conditions for experiments, the results were obtained that : deposition rate faster, $53.33 \mathrm{~g} \cdot \mathrm{m}^{-2} \cdot \mathrm{h}^{-1}$; drop time of $\mathrm{KMnO}_{4}$ solution for $272 \mathrm{~s}$; thickness of $12.43 \mu \mathrm{m}$.

\section{XRD analysis}

Fig. 1 showed XRD patterns of the Ni-Co-P alloy coating formed by the electroless methods. $\mathrm{Mg}$ diffraction peak was not obvious, and It showed that the coating of Ni-Co-P alloy could completely cover the Mg substrate. Obvious characteristic peaks looking like the shape of steamed bread could be observed at about $2 \theta=45^{\circ}$ so as to explain that as-prepared Ni-Co-P alloy coating was in amorphous structure $^{[14]}$.

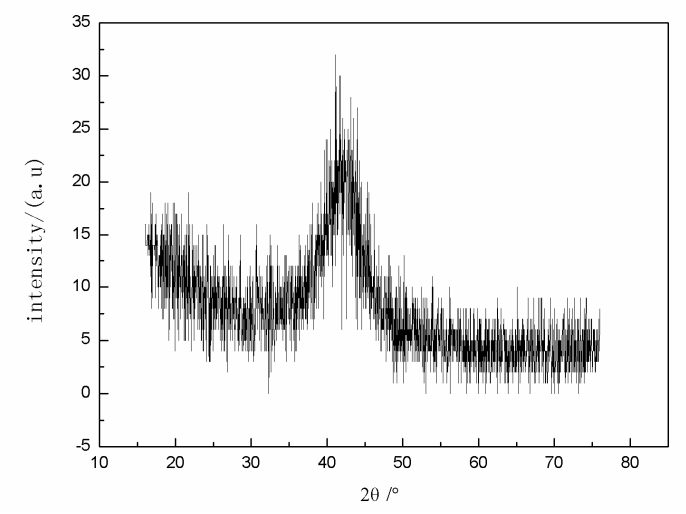

Fig. 1 XRD patterns of Ni-Co-P coating

\section{SEM and EDS analysis}

Fig.2 showed surface structures of as-prepared Ni-Co-P coating. From morphologies of Ni-Co-P coating, The results revealed that all the coatings were cellular structures which were similar to the morphology of Ni-P plating coating, and uniform surfaces structure with no cracks were obtained. Due to a dense and compact Ni-Co-P coating on AZ31B substrate, it contributed to reducing porosity, further to enhancing corrosion resistance of $\mathrm{Ni}-\mathrm{Co}-\mathrm{P}$ coating . Due to owing higher activity of atoms on the interface of the cellular organization, it was the easiest position to begin to produce corrosion ${ }^{[15]}$.

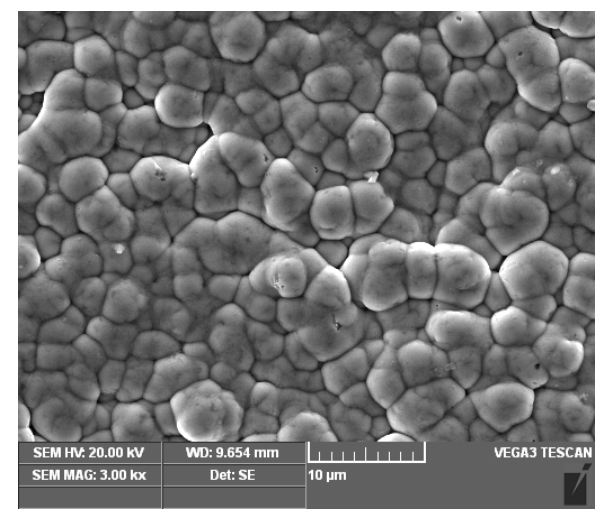

Fig. 2 SEM image of Ni-Co-P coating 
To know the presence and weight percentage of Ni,Co and $\mathrm{P}$ in the Ni-Co-P coatings, energy dispersive X-ray analyzer (EDX) was used. The results of the Ni-Co-P coating were shown in Fig. 3 and Tab. 5. The weight percentage of Ni was found to be 71.32, that for Co was 19.29, and that for $\mathrm{P}$ was 9.40. The compositional analysis mainly confirmed the presence of $\mathrm{Ni}, \mathrm{Co}$ and $\mathrm{P}$ in the coating.

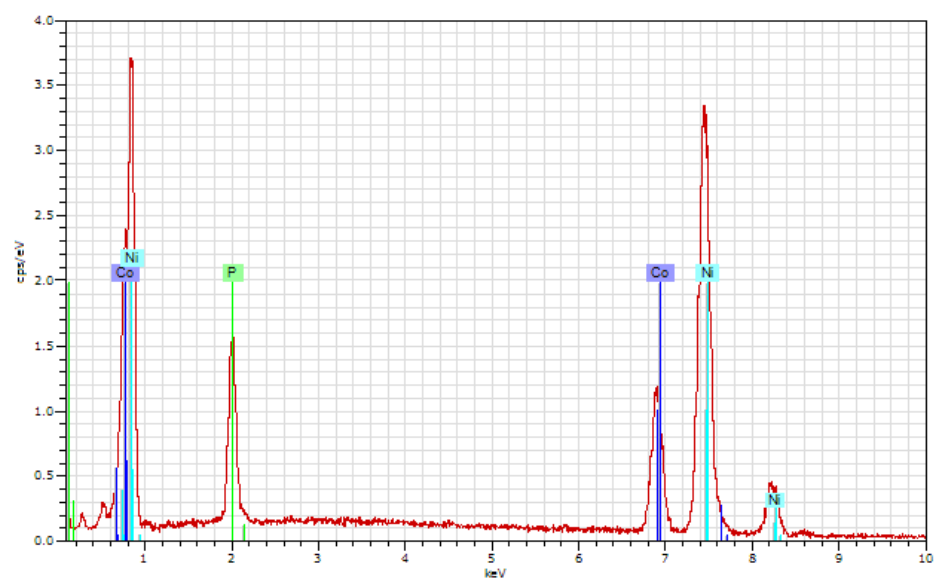

Fig. 3 EDX of Ni-Co-P coating

Tab.5 Composition of Ni-Co-P coating

\begin{tabular}{cccc}
\hline Element & $\mathrm{Ni}$ & $\mathrm{Co}$ & $\mathrm{P}$ \\
\hline $\begin{array}{c}\text { weight percentage } \\
(\text { wt.\%) }\end{array}$ & 71.32 & 19.29 & 9.40 \\
\hline
\end{tabular}

\section{Corrosion properties}

The potentiodynamic polarization measurements were carried out after obtaining the open circuit potential (Eocp). In order to attain the Eocp, the specimens were immersed into the $3.5 \% \mathrm{NaCl}$ corrosive medium to reach a plateau. the Eocp for a Ni-Co-P coating and AZ31B substrate were $-1.237 \mathrm{~V}$ and $-1.952 \mathrm{~V}$ repectively. These results indicated that the Eocp was shifted towards more positive values after Ni-Co-P coating was covered on AZ31B substrate. In other words, the electrochemical stability of the Ni-Co-P coating was much better than the AZ31B substrate without coating in the $3.5 \% \mathrm{NaCl}$ solution. The potentiodynamic polarization curves of the Ni-Co-P alloy coatings in 3.5\% NaC1 solution was illustrated in Fig.4. According to the data of corrosion parameter, the corrosion potential ( Ecorr ) for a Ni-Co-P coating and AZ31B substrate were -1.247 and $-1.524 \mathrm{~V}$ repectively(see Fig.4).the Ecorr of the Ni-Co-P alloy coatings was shifted towards positive values with respect to corrosion potentialof AZ31B substrate. According to the electric potential comparison criterion, the corrosion potential was more positive in the same medium, it was not easier to produce corrosion. Moreover, corrosion resistance of the Ni-Co-P coating was better than AZ31B substrate after plating the Ni-Co-P coating for the electroless. 


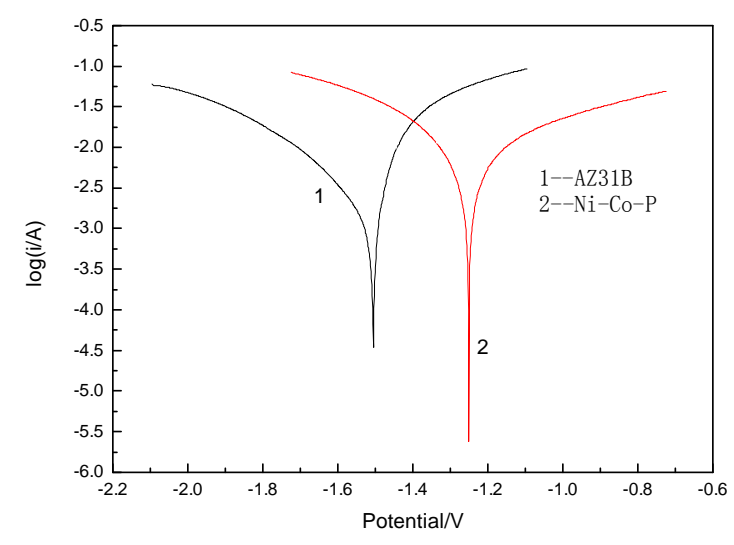

Fig. 4 The potentiodynamic polarization curves of the Ni-Co-P alloy coatings in $3.5 \% \mathrm{NaC} 1$ solution

\section{Hardness and binding force of the coating}

The microhardnesses were measured with HV-5 microhardness tester. The hardnesses of three points were so similar as to be explained for obtained uniform coating. The hardnesses of Ni-Co-P coating and The hardnesses of the blank sample were up to $229.60 \mathrm{HV}$ and $128.74 \mathrm{HV}$ respectively. Hardnesses and wear resistance were obviously enhanced after the plating.After the coating was rasped by using a rasper along with the coating at $45^{\circ}$ four times, there are no peeling, shedding and scratches. It indicated the binding forces between the coating and the substrate were better.

\section{Summary}

In summary, The optimium formula and process conditions had successfully obtained by orthogonal experiment methods in electroless Plating of Ni-Co-P on AZ31B. Ni-Co-P coating hold compact and uniform surface investigated by SEM. as-prepared Ni-Co-P alloy coating was amorphous by using XRD. The results of drop time for $\mathrm{KMnO}_{4}$ solution and the potentiodynamic polarization measurements indicated that Ni-Co-P alloy coating had better corrosion resistance, so they were expected to become a promising treatment methods of metal surface applied in Many industries of national economy.

\section{Acknowledgements}

This work was financially supported by the Opening Project of Material Corrosion and Protection Key Laboratory of Sichuan province (2014CL06), the Science Research Fund of Sichuan Provincal Education Department (14ZB0219) and the Science and Technology Department of Sichuan Province (2014JY0007), Talents Project of Si Chuan University of Science and Engineering (2014RC30), Provincial-level Project of Innovation and Entrepreneurship Training for College Students in 2015 (201510622086), Characteristic Discipline Direction Project of Sichuan University of Science and Engineering(2014TS12).Furthermore, all the authors expressed their deep thanks.

\section{References}

[1] Amani E. Fetohi , R.M. Abdel Hameed , K.M. El-Khatib , Eglal R. Souaya. NieP and NieCoeP coated aluminum alloy 5251 substrates as metallic bipolar plates for PEM fuel cell applications, International Journal of Hydrogen Energy.37(2012)7677-7688.

[2] Anuj Kumar, Mukesh Kumar, Dinesh Kumar. Effect of composition on electroless deposited $\mathrm{Ni}-\mathrm{Co}-\mathrm{P}$ alloy thin films as a diffusion barrier for copper metallization,Applied Surface Science. 258(2012) 7962- 7967 
[3] Parente MMV, Mattos OR, Diaz SL, Neto PL, Miranda FJF.Electrochemical charaterization of $\mathrm{Ni}-\mathrm{P}$ and Ni-Co-P amorphous alloy deposits obtained by electrodeposition,J Appl Electrochem. 31(2001)677-683.

[4]Lew KS, Raja M, Thanikaikarasan S, Kim T, Kim YD,Mahalingam T. Effect of pH and current density in electrodeposited Co-Ni-P alloy thin films ,Mater Chem Phys. 112(2008)249-253.

[5]Li J Z , Tian Y W, Huang Z Q , et al.Studies of the porosity in electroless nickel deposits on magnesium alloy,Applied Surface Science .252(2006 )2839-2846 .

[6]Davod Seifzadeh, Amin Rahimzadeh Hollagh.Corrosion Resistance Enhancement of AZ91D Magnesium Alloy by Electroless Ni-Co-P Coating and Ni-Co-P-SiO2 Nanocomposite,Journal of Materials Engineering and Performance.23(2014)4109-4121.

[7]Anuj Kumar,Amanpal Singh, Mukesh Kumar, et al..Study on thermal stability of electroless deposited Ni-Co-P alloy thin film,Journal of Materials Science: Materials in Electronics. 22(2011)1495-1500.

[8]Tushar Banerjee, R. S. Sen, B. Oraon, et al.. Predicting electroless Ni-Co-P coating using response surface method, The International Journal of Advanced Manufacturing Technology. 64(2013)1729-1736.

[9] Ying Huang, Ke Shi, Zijun Liao, Yanli Wang, Li Wang, Feng Zhu. Studies of electroless Ni-Co-P ternary alloy on glass fibers,Materials Letters .61(2007)1742-1746.

[10] Y. Gao, L. Huang, Z.J. Zheng, H. Li, M. Zhu. The influence of cobalt on the corrosion resistance and electromagnetic shielding of electroless $\mathrm{Ni}-\mathrm{Co}-\mathrm{P}$ deposits on Al substrate,Applied Surface Science.253(2007)9470-9475.

[11]Kumar, A; Kumar, M; Kumar, D.Effect of composition on electroless deposited Ni-Co-P alloy thin films as a diffusion barrier for copper metallization,Applied Surface Science. 258(2012)7962-7967.

[12] TANG Jie ,JIN Yong-zhong,SUN Ya-li,ZUO You-bing.To Measure the Thickness of Films in Micron with the Focal Planes of a Metalloscope. Journal of Sichuan University of Science and Engineering (Natural Science Edition ).19(2006) 108-110.

[13]Fu Chuan, Qi Jun-sheng. Optimization of Technology of Zn-Ni-P Alloy Electroplating by Orthogonal Test,SURFACE TECHNOLOGY.32(2003) 43-45.

[14] Yueping Guo, Qinghua Feng, Jiantai Ma.The hydrogen generation from alkaline NaBH4 solution by using electroplated amorphous Co-Ni-P film catalysts,Applied Surface Science.

273(2013)253-256.

[15]HU Fu,FANG Liang,HU Jia, LI Yun,XIE Liang-bo, WANG Xiao-bing.Corrosion Resistance of Electroless Ni-Co-P Coating Prepared on AZ31B Magnesium Alloy in Acidic Plating Bath,Materials Protection.43(2010)13-15. 